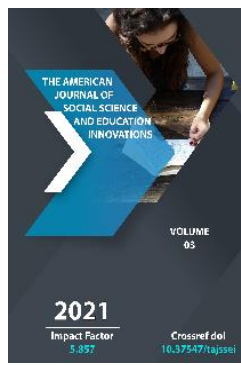

\title{
Teaching Gender-Sensitive Language And Gender-Biased Terminology
}

\author{
Khamdamova Sevarakhon Oybek Qizi \\ Teacher Of The Department Of "Teaching Languages", Faculty Of Management In Production, \\ Fergana Polytechnic Institute, Fergana City, Republic Of Uzbekistan
}

Journal Website:

https://theamericanjou

rnals.com/index.php/ta

jssei

Copyright: Original content from this work may be used under the terms of the creative commons attributes 4.0 licence.

\section{ABSTRACT}

This article will define gender sensitive language and illustrate its importance in communication, especially business writing. In addition, this article examines the reasons for gender sensitive language and gives some examples to gender biased terminology.

\section{KEYWORDS}

Gender, Gender Sensitive Language, Gender Neutral Terms, Gender Biased Terminology.

\section{INTRODUCTION}

Gender became an object of scientific research only in the second half of the twentieth century, but even before the advent of targeted gender studies, the existence of differences in the speech behavior of men and women was not in doubt [3], since gender obviously affects the communicative behavior of participants in communication, regardless of their role in a particular speech act. In addition, speech gender stereotypes, some of which are enshrined in the language (for example, in proverbs and sayings: A woman came from the city, brought news from three boxes; Women know how to keep secrets together), play an important role in our perception of other people [11]. With the developing views on gender issues scientists also paid attention to the creating gender sensitive language which avoids gender discrimination and using gender neutral terms in their speech.Language not only reflects the way writers think; it also shapes the thinking of listeners or readers and influences their behaviour. Word choices often carry unconscious assumptions about gender roles [1]. The use of terms only referring to males is not accepted anymore, as excluding 
women is considered an offence. Language should therefore be used with a high degree of precision [2]. Avoiding discrimination between genders starts with language, as the systematic use of gender-biased terminology influences attitudes and expectations and could, in the mind of the reader, relegate women to the background or help extending the survival of a stereotyped view of masculine and feminine roles. The United Nations directives in that regard invite United Nations staff to avoid to the extent possible the use of language which refers explicitly or implicitly to only one sex, and to ensure (according to each language's characteristics) the use of nonsexist/gender-sensitive/neutral language [5]. These article present the following: - Sex and gender: definition and difference between the two terms; - United Nations official instructions with regard to the use of gender-sensitive language; - Alternatives and solutions to gender-biased language in English - Resources for further reference; - A detailed list of genderbiased language examples and gendersensitive alternatives.

\section{SEX AND GENDER}

Sex: biological and physiological characteristics that define men and women. Sex characteristics do not vary between societies (for example menstruation, reproductive capacity and breast feeding are women's characteristics, while men generally have more massive bones).

Gender: socially constructed attributes, roles, behaviours and activities that a given society considers appropriate for men and women. Gender roles are the activities ascribed to men and women on the basis of perceived societal differences. Gender roles vary greatly between societies: division of labour in families, communities and the marketplace; access to education, health care, job opportunities, financial resources and decision-making roles; and other issues.

\section{Alternatives and solutions to gender-biased language}

When meaning both sexes, we should use a term that includes both. Writers, speakers, teachers, public figures, media persons should examine their language to reduce choices that exclude or stereotype others. Each language has its own characteristics; solutions to gender-biased terms and expressions vary between languages. The following guidelines are mainly for the English language.

With regard to the English language, it is almost always possible to find alternative terms and sentence structures to avoid gender-biased or stereotyping language.

Table 1 .The use of pronouns

\begin{tabular}{|c|c|c|}
\hline № & Examples & Proposed alternatives \\
\hline \multirow{2}{*}{1} & \multirow{2}{*}{$\begin{array}{c}\text { The client should receive his invoice in } \\
\text { two weeks. }\end{array}$} & $\begin{array}{c}\text { The client should receive his or her invoice in } \\
\text { two weeks (alternately reverse order: her or } \\
\text { his). }\end{array}$ \\
\cline { 3 - 3 } & & $\begin{array}{c}\text { The client should receive the (or an) invoice in } \\
\text { two weeks. }\end{array}$ \\
\cline { 3 - 3 } & & $\begin{array}{c}\text { The invoice will be sent to the client in two } \\
\text { weeks. }\end{array}$ \\
\hline \multirow{2}{*}{2} & $\begin{array}{c}\text { Each participant must present his ID } \\
\text { badge at the door. }\end{array}$ & $\begin{array}{c}\text { All participants must present their ID badges } \\
\text { at the door. }\end{array}$ \\
\hline
\end{tabular}


The American Journal of Social Science and Education Innovations (ISSN - 2689-100x)

Published: September 29, 2021 | Pages: 28-33

Doi : https://doi.org/10.37547/tajssei/Volume03Issue09-07

\begin{tabular}{|c|c|c|}
\hline & & $\begin{array}{l}\text { Each participant must present his/her ID } \\
\text { badge at the door. }\end{array}$ \\
\hline \multirow{2}{*}{3} & \multirow{2}{*}{$\begin{array}{l}\text { A good judge relies, to some degree, on } \\
\text { his common sense. }\end{array}$} & $\begin{array}{l}\text { A good judge relies, to some degree, on } \\
\text { common sense. }\end{array}$ \\
\hline & & $\begin{array}{c}\text { A good judge relies, to some degree, on his or } \\
\text { her common sense. }\end{array}$ \\
\hline \multirow[b]{2}{*}{4} & \multirow{2}{*}{$\begin{array}{l}\text { The teacher is usually appointed on the } \\
\text { basis of his training. }\end{array}$} & $\begin{array}{l}\text { Teachers are usually appointed on the basis of } \\
\text { their training. }\end{array}$ \\
\hline & & $\begin{array}{c}\text { A teacher is usually appointed on the basis of } \\
\text { her or his training. }\end{array}$ \\
\hline
\end{tabular}

Table 2.Exclusionary terms

\begin{tabular}{|c|c|c|}
\hline № & Examples & Proposed alternatives \\
\hline 1 & Man Person; & individual; human being \\
\hline 3 & Chairman & $\begin{array}{r}\text { Humanity; human beings; people; men and } \\
\text { women }\end{array}$ \\
\hline 4 & Spokesman & $\begin{array}{r}\text { Chairperson; chair; president (in certain cases) } \\
\text { Spokesperson; representative; (when talking } \\
\text { about a specific person: Mr. John is the } \\
\text { spokesman of the President; Ms. Jeanette } \\
\text { Walker is the spokeswoman of the President) }\end{array}$ \\
\hline
\end{tabular}

\section{Stereotyping roles and attributes}

Do not represent certain jobs as only appropriate or held by women or men.

Examples to be avoided:

- Professors are men and elementary teachers are women;

- Politicians are men and women are wives;

- Housework is the duty of women and an option or out of question for men;

- Scientists are men and secretaries are women;

- Doctors are men and nurses are women. Do not represent women and men as possessing stereotypic gendered attributes.

Examples to be avoided:

- Men are independent; women are dependent;

- Men are admired for their accomplishments, women for their physical attributes; - Men are active; women are passive;

- Men are ambitious; women are modest;

- Men are leaders; women are followers [6]. 
Table 3.

\begin{tabular}{|c|c|c|}
\hline № & Examples & Proposed alternatives \\
\hline 1 & $\begin{array}{l}\text { John and Mary both have full-time jobs; } \\
\text { he helps her with the housework. }\end{array}$ & $\begin{array}{l}\text { John and Mary both have full-time jobs; they } \\
\text { share the housework. }\end{array}$ \\
\hline 2 & $\begin{array}{l}\text { Transport will be provided for delegates } \\
\text { and their wives. }\end{array}$ & $\begin{array}{l}\text { Transport will be provided for delegates and } \\
\text { their spouses or persons accompanying them. }\end{array}$ \\
\hline 3 & $\begin{array}{l}\text { A nurse knows that every day she will } \\
\text { touch a life or a life will touch hers. }\end{array}$ & $\begin{array}{l}\text { A nurse knows that every day she/he will } \\
\text { touch a life or a life will touch hers/his (or use } \\
\text { the plural). }\end{array}$ \\
\hline 4 & Maria is a career woman. & $\begin{array}{l}\text { Maria is a professional. Maria is an engineer } \\
\text { (do we say John is a career man?) }\end{array}$ \\
\hline
\end{tabular}

Table 4. Personal titles

\begin{tabular}{|c|c|c|}
\hline № & Examples & Proposed alternatives \\
\hline 1 & Miss, Mrs. & $\begin{array}{r}\text { Ms. (unless the woman herself prefers the } \\
\text { courtesy title Mrs. or Miss). A woman's } \\
\text { marital status is very often irrelevant to the } \\
\text { matter in hand. }\end{array}$ \\
\hline 2 & Mr. and Mrs. John Smith & $\begin{array}{r}\text { Mr. and Mrs. Smith; or Jane and John Smith; } \\
\text { or Mrs. Jane and Mr. John Smith }\end{array}$ \\
\hline 3 & Mrs. Michael Austen & Ms. Patricia Austen \\
\hline
\end{tabular}

\section{CONCLUSION}

Business writing is a tool which enables business authorities stay in touch with employees, customers and with people in general. Consideration of gender sensitivity in writing, using of non-discriminatory, inclusive forms makes employees and customers feel important and respected. That is not only a source of business prosperity and prot but it is also a way to build solid bridge between society and business as they are interdependent. Gender sensitivity in business English writing can boost devotion, dedication and feeling of equality, loyalty and respect in community. These are main features which enables business to build strong foundation of success and further development. Business writing is a tool which enables business authorities stay in touch with employees, customers and with people in general. Consideration of gender sensitivity in writing, using of non-discriminatory, inclusive forms makes employees and customers feel important and respected. That is not only a source of business prosperity and prot but it is also a way to build solid bridge between society and business as they are interdependent. Gender sensitivity in business English writing can boost devotion, dedication and feeling of equality, loyalty and respect in 
community. These are main features which enables business to build strong foundation of success and further development. Business writing is a tool which enables business authorities stay in touch with employees, customers and with people in general. Consideration of gender sensitivity in writing, using of non-discriminatory, inclusive forms makes employees and customers feel important and respected. That is not only a source of business prosperity and prot but it is also a way to build solid bridge between society and business as they are interdependent. Gender sensitivity in business English writing can boost devotion, dedication and feeling of equal-ity, loyalty and respect in community. These are main features which enables business to build strong foundation of success and further development. Consideration of gender sensitivity in writing, using of non-discriminatory, inclusive forms makes employees and customers feel important and respected. Gender sensitivity in English can boost devotion, dedication and feeling of equality, loyalty and respect in community. Although this is important in terms of equal visibility and treatment of women and men, we would like to stress the importance of going beyond the binary notion of gender. As such, try to consider gender as a continuum in your communications and discourse, to encompass all those that identify themselves neither with women nor with men. Finally, we would also like to stress that communication naturally encompasses visual communication. As such, you should also always think about your visual representations as inclusive, and as not giving visual priority to one gender over another, for example, by setting men in the front of a picture and women at a farther distance (or men in the centre and women in the periphery).

\section{REFERENCES}

1. Bodine, A. (1975). Androcentrism in prescriptive grammar: singular 'they', sexindefinite 'he', and 'he or she'1. Language in society, 4(2), 129-146.

2. Eagly, A. H. (1987). John M. MacEachran memorial lecture series; 1985. Sex differences in social behavior: A social-role interpretation. Hillsdale, NJ, US: Lawrence Erlbaum Associates, Inc.

3. Foertsch, J., \& Gernsbacher, M. A. (1997). In search of gender neutrality: Is singular they a cognitively efficient substitute for generic he?. Psychological science, 8(2), 106-111. doi: 10.1111/j.14679280.1997.tboo691.x

4. Gabriel, U. \& Gygax, P. (2016). Gender and linguistic sexism. In Giles, H. \& Maass, A. (eds). Advances in intergroup communication (pp. 177-192). New York: Peter Lang.

5. Gabriel, U., Gygax, P. M., \& Kuhn, E. A. (2018). Neutralising linguistic sexism: Promising but cumbersome?. Group Processes \& Intergroup Relations, 21(5), 844-858. doi: 10.1177/1368430218771742.

6. Hegarty, P., Mollin, S., \& Foels, R. (2016). Binomial word order and social status.

7. Hegarty, P., \& Bruckmüller, S. (2013). Asymmetric explanations of group differences: Experimental evidence of Foucault's disciplinary power. Social and Personality Psychology Compass, 7(3), 176186. doi:10.1111/spco.2013.7.issue-3

8. Kahneman, D., \& Tversky, A. (1996). On the reality of cognitive illusions.

9. Parzuchowski, M., Bocian, K., \& Gygax, P. (2016). Sizing up objects: The effect of diminutive forms on positive mood, value, and size judgments. Frontiers in 
Psychology, $\quad 1452$.

https://doi.org/10.3389/fpsyg.2016.01452

10. Slobin, D. I. (2003). Language and thought online: Cognitive consequences of linguistic relativity. Language in mind: Advances in the study of language and thought, 157192.

11. Stout, J. G., \& Dasgupta, N. (2011). When he doesn't mean you: Gender-exclusive language as ostracism. Personality and Social Psychology Bulletin, 37(6), 757-769.

12. Viennot, E. (2014). Non, le masculin ne l'emporte pas sur le féminin! Editions IXE.

13. Wyrobková, A., Gygax, P., \& Macek, P. (2015). Human and man side by side, woman trapped in a different reality: word associations in Czech. Ceskoslovenska Psychologie, 59(1).

14. https://www.unescwa.org/sites/default/fil es/services/doc/guidelines_gender-

sensitive_language_e-a.pdf

15. Guidelines for Non-Sexist Use of Language from the American Philosophical Association-

https://www.apaonline.org/page/nonsexi st

16. General Principles for Reducing Bias from the American Psychology Association https://apastyle.apa.org/style-grammarguidelines/bias-free-language/generalprinciples

17. Non-Sexist Language Reloaded, University of Lancaster (RiGLS)

https://www.lancaster.ac.uk/media/lancas teruniversity/contentassets/images/athenaswan/BrochureSexistLanguage_final.pdf 